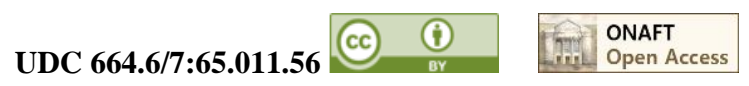

DOI https://doi.org/

O. Gaponyuk, Doctor of Technical Sciences, Professor, E.mail: oleg_odessa@me.com RESEARCHERID.com/rid/U-7792-2017, ORCID.org/0000-0002-9577-4417

A. Aleksashin, Ph.D., Associate professor, E.mail: aleksashin48@gmail.com RESEARCHERID.com/rid/U-7832-2017, ORCID.org/0000-0001-6423-4605

G. Goncharuk, Ph.D., Associate Professor, E.mail: ganna.goncharuk22@ gmail.com RESEARCHERID.com/rid/U-7642-2017, ORCID.org/0000-0002-8361-0810 Odessa National Academy of Food Technologies, 112, Kanatna Str., Odessa, 65039, Ukraine

\title{
IT SERVICE OF THE MODERNIZED GRAIN MOISTURIZING MACHINE
}

\begin{abstract}
The purpose of this work is to increase the efficiency of the grain humidifier, which is part of the system for preparing grain for grinding, ensuring the reliability of machines, its productivity, reducing energy consumption and improving the quality of the finished product. products by introducing automation based on SMART technology, defined as self-monitoring and reporting technology.

SMART technology is inextricably linked with a monitoring and data collection system designed to monitor and automatically manage a large number of remote, geographically dispersed sites. In addition, this system provides long-term archiving of the received data, which allows the dispatcher to monitor the operation of the relevant equipment, responding with an IT service program.

A remote automated monitoring and control system for the production line on which the dampening machine is installed ensures optimum performance. Rotary machines for grain moistening are considered. At flour mills, as well as at other enterprises, such machines are used at the stage of main moistening and for additional moistening before feeding the grain to the grinding workshop. A1-BShU-2 machines are designed for basic grain moistening.

Humidifiers are installed in front of the grain bins in the production lines of the preparatory departments of flour mills to remove excess moisture. At the same time, machines for washing grain and, accordingly, all equipment for treating wastewater and treated waste can be excluded from the technological schemes of enterprises, therefore, an urgent task is to increase productivity. Air humidifier A1-BShU-2 by improving the design of the working body and automation of the machine. generally.

In this regard, it is necessary to intensify the process of moistening the grain due to the optimal location of the blades for moving the grain (races) and mixing (whips) on the shaft of the working body, apply a drive motor speed control system using a frequency converter.

The article shows ways to improve the performance of a humidifier, as well as issues of control and management of the optimal mode of its operation. For example, Table 1 is presented in the form of a layout, which shows in what form the information can be provided to the operator and stored in the archive.
\end{abstract}

Key words: rotating rotor, whips, races, SMART technologies, service IT equipment.

\section{Introduction}

The technological process of grain moistening is a set of equipment that works in this sequence. From the hopper through the scales the grain enters the separator. Here it is cleaned of large, small and light impurities, then, passing through a magnetic column, is released from metal-magnetic particles and fed sequentially to the trier: pupa and oatmeal, which separates impurities that differ from the grains of the main crop in length. The grain cleaned of impurities enters the upholstery machine for cleaning the surface of the grains from dust and partial separation of fruit skins and germ. In the humidifier, the grain is moistened and then transported to the hopper for humidification and further to the line. These machines allow to introduce into the grain up to $5 \%$ of moisture due to its mixing with blades - whips of a highspeed rotor [1]. Machines A1-BSHU-2 are used for the basic moistening of grain. In the production lines of the preparatory departments of flour mills they are installed in front of the aging hoppers. Thus from schemes of the enterprises exclude washing or washing-peeling cars and, accordingly, all equipment for processing of sewage and washing waste $[1,3]$,] therefore the task of increase of productivity of the humidifying A1-BSYU-2 car by improvement of structure of working is actual. body. In this regard, it is necessary to intensify the process of wetting the grain through the use of control and management, the speed of rotation of the main working body using the frequency converter of the drive motor.

\section{Research methodology}

The use of waterjet machines in the flourmilling industry allows to dispense water quite accurately in proportion to the amount of grain. However, uniform wetting of its surface does not occur, and therefore requires devices that can further mix the moistened grain mixture. More uniform wetting of the grain surface is achieved in machines in which water is supplied in a sprayed state.

Machine A1-BSHU-1 consists of the following main components: housing, whip rotor, drive, frame, indicator of the presence of grain, water supply control system. The case is made of stainless steel and has a connector in the horizontal plane. Both halves are connected by bolts. From the ends of the case to walls bolts of support for installation of cases of bearings are attached. The body of the machine has receiving and exhaust pipes.

The main working body is a rotor, which rotates in two bearing bearings with spherical double-row ball bearings. Rotation - from the electric motor, through a Vbelt transmission. The electric motor and the microswitch have dust protection executions. The two halves of the 
housing, which has a horizontal plane of the connector, are made of sheet steel with a thickness of $1 \mathrm{~mm}$. The main task and selection criterion was to increase the productivity of the humidifying machine. To solve the main task of improvement, the basis was to change the location of the races on the bulls. The working races of the four sides are set with the plane to the axis of the rotor at an angle of $60^{\circ}$ and the reflective races of the other four sides are set at an angle of $70^{\circ}$ (Fig. 1). In addition, it is necessary to increase the intensification of the humidification process by using the speed control system of the main working body.

The grain after processing in the triers comes through the receiving pipe 1 on the indicator of the presence of grain (Fig. 2). Under the action of the grain flow, the plate with the lever 2 is deflected and the microswitch closes the electrical circuit. The solenoid valve 4 is activated and opens the hole for water supply from the water supply through the pressure regulator, filter, solenoid valve, needle valve and rotameter 3 in the working area. Where due to the special arrangement of the rotor (hollow drum 5, to which are fixed the whips 10 with shoulder blades9) and the high frequency of its rotation, the grain is intensively mixed, saturated with moisture and moves from reception to release. The rotor rotates in two bearing bearings 7 having spherical two-row ball bearings. Rotation of the rotor - from the electric motor 11 through the V-belt transmission 12.

Taking into account the above, we will determine the optimal parameters of the dampening machine, as well as the ways of monitoring, analyzing and promptly taking the necessary measures for the stable functioning of the technological and transport equipment of the flour mill. We will carry out the necessary calculations and directions of operational control of the technological process.
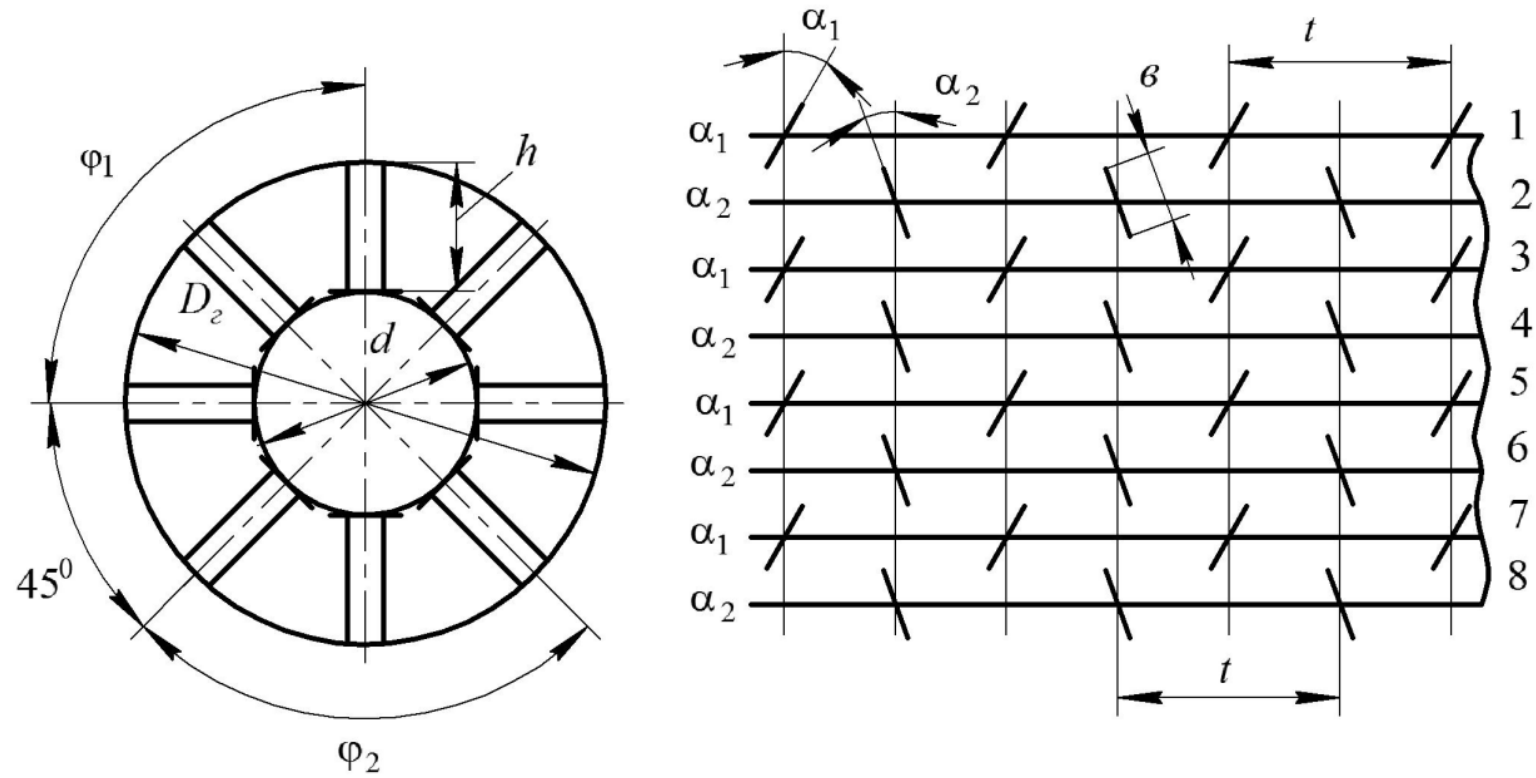

Fig. 1. Diagram of the location of the shoulder bladeson the whips of the races (working body) of the humidifying machine

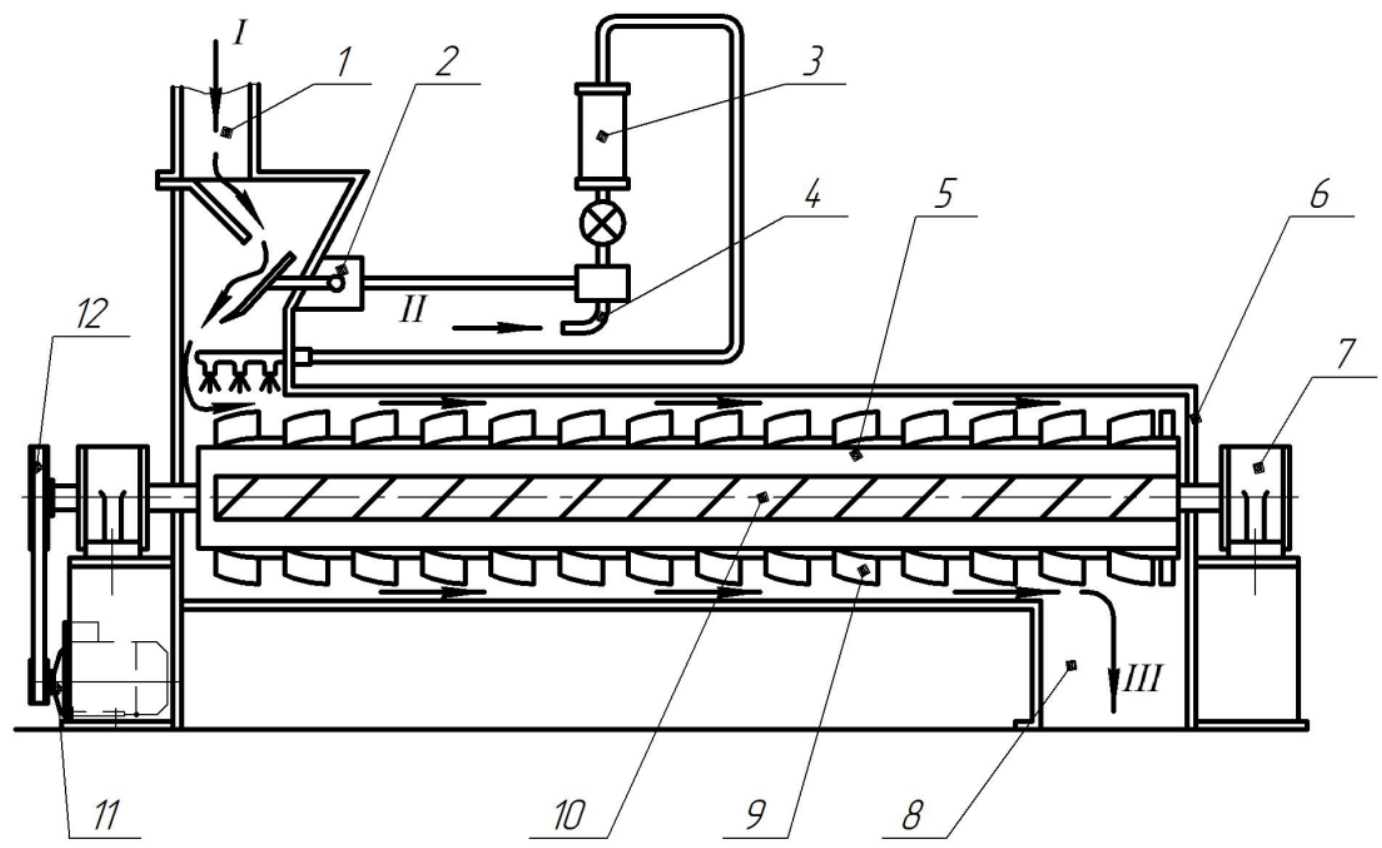

Fig. 2. Functional diagram of the humidifying machine 


\section{Research results}

\section{Initial data for calculation:}

Declared performance $\mathrm{P}=7 \mathrm{t} / \mathrm{h}$; outer diameter of the working body $D_{w b}=264 \mathrm{~mm}$; rotor diameter $d=140 \mathrm{~mm}$; height of the working body $h=50 \mathrm{~mm}$; body diameter $D_{b}=300 \mathrm{~mm}$; the inner diameter of the working body

$$
d_{w b}=D_{w b}-2 h=264--250=164 m m ;
$$

number of whips $Z_{w}=8$; step of installation of working bodies on a whip $t=100 \mathrm{~mm}$; working races of four sides are established by a plane to an axis of a rotor at an angle $\alpha_{1}=60^{\circ}$; the reflective races of the other four sides are set at an angle $\alpha_{2}=70^{\circ}$; the angle of displacement of the same type of working bodies in cross section $\varphi_{1}=\varphi_{2}=90^{\circ}$; width of the working body $b=40 \mathrm{~mm}$; bulk density of wheat grain $\gamma=650 \frac{\mathrm{kilo}}{\mathrm{m}^{3}}$.

\section{Calculation:}

Machine performance:

$$
P=60\left(Q_{v p 1}-Q_{v p 2}\right) n \gamma \frac{k i l o}{h},
$$

where $\mathrm{n}$ - is the rotor speed;

$Q_{v p 1}$ i $Q_{v p 2}$ volumetric productivity for one revolution of a rotor for whips with working bodies and according to those reflecting.

$$
Q_{v p}=\frac{\pi\left(D_{w b}^{2}-d_{w b}^{2}\right)}{4} S k_{c f} k_{p r} \frac{m^{3}}{t u r n},
$$

where $k_{c f}-$ is the coefficient of fragmentation of the working bodies; $k_{p r}-$ is presentation ratio; $S-$ is pitch helical race surface.

Determine the average diameter of the working bodies:

$$
\begin{gathered}
D_{a d}=D_{w b}-h m m, \\
D_{a d}=264-50=214 \mathrm{~mm} .
\end{gathered}
$$

Determine the pitch of the helical surface of the working bodies:

$$
S=\frac{\pi D_{a d}}{\operatorname{tg} \alpha} m
$$

for working bodies installed at an angle $\alpha_{1}=60^{\circ}$

$$
S_{1}=\frac{3,140,214}{\operatorname{tg} 60^{\circ}}=0,388 \mathrm{~m},
$$

for reflecting working bodies established at an angle $\alpha_{2}=70^{\circ}$

$$
S_{2}=\frac{3,140,214}{\operatorname{tg} 70^{\circ}}=0,244 \mathrm{~m} \text {. }
$$

The length of the helical surface of one step of the turn of the working bodies:

$$
L=\sqrt{\left(\pi D_{a d}\right)^{2}+S^{2}} m,
$$

$$
\begin{aligned}
& L_{1}=\sqrt{(3.140 .214)^{2}+0.388^{2}}=0.776 \mathrm{~m}, \\
& L_{2}=\sqrt{(3.140 .214)^{2}+0.244^{2}}=0.715 \mathrm{~m} .
\end{aligned}
$$

The area of the helical surface of one turn:

$$
\begin{gathered}
F_{s}=L_{h m^{2}}, \\
F_{s 1}=0.7760 .05=0.0388 m^{2}, \\
F_{s 2}=0.7150 .05=0.03575 m^{2} .
\end{gathered}
$$

At a step of installation of working bodies on a whip $t=0.1 \mathrm{~m}$ we define quantity of races on one step of a screw surface:

$$
\begin{aligned}
Z_{s} & =\frac{S}{t}, \\
Z_{s 1} & =\frac{0.388}{0.1}=3.88, \\
Z_{s 2} & =\frac{0.244}{0.1}=2.44 .
\end{aligned}
$$

The area of the working bodies on one step of the helical surface:

$$
\begin{aligned}
& F_{w b s}=h \text { в } Z_{s} m^{2}, \\
& F_{w b s 1}=0,050,043,88=0,00776 m^{2} \text {, } \\
& F_{w b s 2}=0,050,042,44=0,00448 m^{2} \text {. }
\end{aligned}
$$

Determine the coefficient of fragmentation of the working bodies $k_{c f}$ :

$$
\begin{aligned}
& k_{c f}=\frac{F_{w b s}}{F_{s}}, \\
& k_{c f 1}=\frac{0,00776}{0,0388}=0,2, \\
& k_{c f 2}=\frac{0,00448}{0,03575}=0,125 .
\end{aligned}
$$

Volumetric productivity for one rotation of the rotor according to the formula (2) (we accept the presentation coefficient $k_{p r}=0,1$ )

$Q_{v p 1}=\frac{3,14\left(0,264^{2}-0,164^{2}\right)}{4} 0,3880,20,1=0,00026 \frac{\mathrm{m}^{3}}{\text { turn }}$

$Q_{v p 2}=\frac{3,14\left(0,264^{2}-0,164^{2}\right)}{4} 0,2440,20,125=0,000102 \frac{\mathrm{m}^{3}}{\text { turn }}$

Determine the speed of the rotor using the formula (1)

$$
\begin{gathered}
n=\frac{\Pi}{60\left(Q_{v p 1}-Q_{v p 2}\right) \gamma} \frac{\text { turn }}{\text { minute }}, \\
n=\frac{7000}{60(0,00026-0,000102) \gamma}=1136 \frac{\text { turn }}{\text { minute }},
\end{gathered}
$$


When the diameter of the body $D_{b}=300 \mathrm{~mm}$ and the diameter of the rotor $d=140 \mathrm{~mm}$ determine the cross-sectional area of the grain in the machine:

$$
\begin{gathered}
F_{g}=\frac{\pi\left(D_{b}^{2}-d^{2}\right)}{4} m^{2}, \\
F_{g}=\frac{3,14\left(0,3^{2}-0,14^{2}\right)}{4}=0,0552 m^{2} .
\end{gathered}
$$

At the time of grain processing in the machine $\tau=35 c$ determine the required length of the rotor:

$$
\begin{aligned}
L_{r} & =\frac{P \tau}{3600 F_{g} \gamma} m \\
L_{r} & =\frac{700035}{36000,0552650}=1,9 m
\end{aligned}
$$

Determine the number of working bodies:

$$
Z_{w b}=\frac{L_{r}-t}{t} \frac{360}{\varphi_{1}}=\frac{1.9-0.1}{0.1} \frac{360}{90}=72 .
$$

Determine the number of reflecting bodies:

$$
Z_{r b}=\frac{L_{r r}-t}{t} \frac{360}{\varphi_{2}}=\frac{1.9-0.1}{0.1} \frac{360}{90}=72 .
$$

The total number of bodies:

$$
Z_{b}=Z_{w b}+Z_{r b}=72+72=144 .
$$

Thus, the efficiency of the humidifying machine can be achieved through the following indicators:

$$
\text { - machine performance } P=7 \frac{t}{h} \text {, the optimal }
$$

speed of the rotor of the machine $n=1136$ turn/minute, rotor length $\mathrm{L}_{\mathrm{r}}=1,9 \mathrm{~m}$; number of working bodies $\mathrm{Z}_{\mathrm{wb}}=$ 72 ; the number of reflecting bodies $Z_{\mathrm{rb}}=72$, the total number of bodies $Z_{b}=144$.

- on technological and kinematic characteristics of work of the car for moistening of grain essentially influence - speed of rotation of a rotor, an arrangement and quantity of bodies, an inclination of whips;

- the performance of the humidifying machine depends on the increase in moisture in the grain, which is determined by the specific water consumption; operation of the humidifying machine in the production line must use the following technical means, as well as computer equipment:

- organization of an automated operator's workplace based on a personal computer with a control system and data collection, designed for monitoring and automatic control of a large number of remote, geographically distributed objects and visualization of the state of technological and transport equipment, control over it, archiving parameters;

- temperature sensors of bearings of the driving electric motor, reducer, bearing supports of the working shaft of the humidifying machine;

- control of grain consumption and water supply by means of the executive mechanism in the working chamber of the humidifying machine;

- grain moisture sensor at the outlet of the working chamber of the humidifier;

- control and management of the frequency of rotation of the drive motor of the humidifying machine;

- control of current load of the driving electric motor of the humidifying machine.

The most important component of the remote automated control system is the need to receive service messages. The current service messages are used to implement the dialog mode of the control system and the operator. Such messages are accompanied by an audible signal to attract the attention of the operator and are displayed on the control field in the central part of the monitor of the personal computer of the automated workplace. To confirm to the control system that the operator has read the message, it must press the interactive button "acknowledge" and the button "close", ie turn off the automatic warning sound alarm.

Table 1 - Example of presenting alarm messages

\begin{tabular}{|c||c||c||c||c||}
\hline \multicolumn{5}{|c||}{ Archive of messages } \\
\hline \hline \multicolumn{5}{|c||}{ Emergency For the period from 01.10.2021. to 31.10.2021. } \\
\hline \hline Date & Time & Name & Messages \\
\hline \hline 03.10 .21$. & 14.11 .29$. & Humidifier & Not ready for work. Check all sensors & Administrator \\
\hline \hline 03.10 .21$. & 14.12 .30$. & Humidifier & Not ready for work. Check all sensors & OnepaTop \\
\hline \hline 05.10 .21$. & 10.22 .36$. & Humidifier & Backpressure sensor triggered & Administrator \\
\hline \hline 05.10 .21$. & 10.23 .13$. & Humidifier & Backpressure sensor triggered & Operator \\
\hline \hline 24.10 .21 & 16.10 .21 & Humidifier & Water flow meter does not work & Administrator \\
\hline \hline 24.10 .21$. & 16.11 .32$. & Humidifier & Water flow meter does not work & Operator \\
\hline \hline
\end{tabular}

\section{Conclusions}

All service messages are stored in the archive of technological messages, available for viewing and further correct analysis of the operator and the state of the technological process, in general, and each technological object, in particular, at any time required by the need for
IT service equipment. In this case, the archive table consists of the following columns - date, time, message text, and all technological messages depicted in different colored backgrounds are divided into:

- emergency (red background);

- warning (yellow background); 
- auxiliary (blue background);

- equipment condition (green background);

- logical messages (gray background).

Duplicating a message on a white background captures the time of acknowledgment by the operator of the received message. For example, table 1 is shown in the form of a layout, which shows in what form the information can be provided to the operator and stored in the archive.

\title{
REFERENCES
}

1. Technological equipment predpriyatiy otryasli (grain processing enterprises) / L.A. Glebov, A.B. Demsky, V.F. Vedenev and others - M .: DeLi print, 2006, -816p.

2. Technological equipment of flour and cereal enterprises: a textbook/O.I.Gaponyuk, L.S. Soldatenko, L.G. Grosul et al. - Kherson: Oldi-plus, 2018. - 752p.

3. . Galkina L.S. Technique and technology of flour production on complete equipment / L.S. Galkina, V.A. Butkovsky, G.E. Ptushkina. M .: VO Agropromizdat, 1987.- 191p.

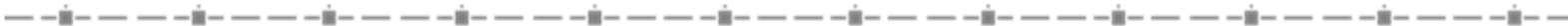

О.І. Гапонюк, д-р техн. наук, професор, E.mail: oleg_odessa@me.com О.В. Алексашин, канд. техн. наук, доцент, E.mail: ganna.goncharuk22@ gmail.com Г.А. Гончарук, канд. техн. наук, доцент, E.mail: aleksashin48@gmail.com Одеська національна академія харчових технологій, вул. Канатна, 112, Одеса, 65039, Украӥна

\section{IT-СЕРВІС МОДЕРНІЗОВАНОЇ МАШИНИ ДЛЯ ЗВОЛОЖЕННЯ ЗЕРНА}

\begin{abstract}
Анотація
Метою даної роботи є підвищення ефективності роботи зволожувача зерна, щуо входить в ділянку підготовки зерна до помелу, для забезпечення надійності роботи машин, ї̈ продуктивності, зменшення енергетичних витрат, поліпшення якості готової продукиії иляхом впровадження автоматизації на основі SMART-технології, щяо визначається як технологія самоконтролю та звітності. Технологія SMART нерозривно пов'язана з системою диспетчерського управління та збору даних, призначена для здійснення моніторингу та автоматичного контролю великого числа видалених, територіально розподілених об'єктів. Крім того, дана система забезпечує довгострокове архівування отриманих даних, щцо дозволяє диспетчеру спостерігати за роботою відповідного обладнання, реагуючи з допомогою програми IT-сервісу. Система дистаниійного автоматизованого контролю та управління потокової лінії, в якій встановлена зволожувальна машина, забезпечує оптимальний режим ї̈ роботи. Розглянуто роторні машини для зволоження зерна. У комплектних борошномельних заводах, а також на інших підприємствах такі машини застосовують на етапі основного зволоження і для дозволоження перед подачею зерна у розмольне відділення. Для основного зволожування зерна використовують машини А1-БШУ-2. У потокових лініях підготовчих відділень борочномельних заводів їх встановлюють перед відлежувальними бункерами. При иъому із технологічних схем підприємств виключають мийні або мийно-лущильні машини і, відповідно, усе обладнання для обробки стічної води і мийних відходів, тому актуальною є задача підвищення продуктивності зволожувальної мамини А1БШУ-2 шляхом удосконалення структури робочого органу і автоматизації роботи машини в цілому. У зв'язку з ичим необхідно інтесифікувати процес зволоження зерна шляхом оптимального розташування гонків та бічив на валу робочого органу, застосувати систему управління швидкості обертання приводного електродвигуна за допомогою частотного перетворювача. В роботі показано шляхи підвищення продуктивності зволожувальної машини, а також питання контролю $i$ управління ії оптимального режиму функиіонування. Для прикладу наведена таблиия 1 у вигляді макету, де показано в якому вигляді інформачія може надаватися оператору $і$ зберігається в архіві.
\end{abstract}

Ключові слова: обертаючий ротор, бічі, гонки, привод, SMART-технологї̈, IT-сервіс обладнання.

\section{ЛIТЕРАТУРА}

1. Технологическое оборудование предприятий отрясли (зерноперерабатывающие предприятия): учебник / Л.А. Глебов, А.Б. Демский, В.Ф.Веденев и др.- М.: ДеЛи принт, 2006,-816с.

2. Технологічне обладнання борошномельних і круп'яних підприємств : підручник / О.І. Гапонюк, Л.С. Солдатенко, Л.Г. Гросул и др. - Херсон : Олді-плюс, 2018. - 752c.

3. Галкина Л.С. Техника и технология производства муки на комплектном оборудовании / Л.С.Галкина, В.А.Бутковский, Г.Е.Птушкина. М.: ВО Агропромиздат, 1987.- 191с.

\section{Received 03.04.2021 \\ Reviewed 29.04.2021}

Revised 12.06.2021

Approved 24.06.2021

Cite as Vancouver Citation Style

Gaponyuk O., Aleksashin A., Goncharuk G. It service of the modernized grain moisturizing machine. Grain products and mixed fodder's, 2021; 21 (2, 82): 14-18. DOI https://doi.org/

Cite as State Standard of Ukraine 8302:2015

It service of the modernized grain moisturizing machine. / Gaponyuk O. et al. // Grain Products and Mixed Fodder's. 2021. Vol. 21, Issue 2 (82). P. 14-18. DOI https://doi.org/

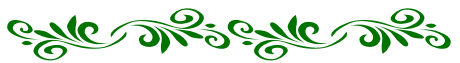

